\title{
Life history traits of the Chinese minnow Rhynchocypris oxycephalus in the upper branch of Yangtze River, China
}

\author{
Yangyang Liang ${ }^{1,2}$, Xiaoyun Sui ${ }^{1,3^{*}}$, Yifeng Chen ${ }^{1}$, Yintao Jia $^{1}$ and Dekui $\mathrm{He}^{1}$
}

\begin{abstract}
Background: Study of the life history traits of any species plays an essential role for understanding their relationship with the surrounding environment and scientific management. The Chinese minnow Rhynchocypris oxycephalus, an ecologically and economically important species which was widely distributed in East Asia, is currently diminishing. In the present study, we depicted the main life history traits of $R$. oxycephalus for the first time.

Results: A total of 442 individuals were collected from April 2012 to March 2013, with total length (TL) ranging from 32.2 to $158.0 \mathrm{~mm}$. The otolith (lapillus) was proved suitable for age determination. Moreover, the results from marginal increment ratio (MIR) analyses demonstrated its unusual growth pattern: two pairs of opaque and transparent bands were formed each year, which might provide some implications for the age determination of other species. The maximum age for females (4 years) was higher than for males (3 years), while 1- and 2-year-old individuals dominated the population. Both females and males reached maturity at 1 year, and the TL at first maturity was $78.8 \mathrm{~mm}$ for females and $60.3 \mathrm{~mm}$ for males. Obvious sexual dimorphism was observed as females growing faster and larger than males after maturity. As a multiple spawner, R. oxycephalus releases batches of eggs from April to August. The fecundity of $R$. oxycephalus was higher, and the size of eggs was larger than that of its closely related species.

Conclusions: $R$. oxycephalus is a short-lived, fast-growing, highly fecund, and early-maturing species; therefore, even a short recovery time after overexploitation or disturbance would be of great use for their restoration. Some life history traits of $R$. oxycephalus demonstrate obvious differences with its closely related species, indicating that latitude and local environment conditions are important selective forces for this species.
\end{abstract}

Keywords: Annuli; Otolith; Age determination; Growth pattern; Reproduction

\section{Background}

The Rhynchocypris minnows are typical small cold water fish, mainly distributed in Asia (Chen 1998). The Chinese minnow Rhynchocypris oxycephalus (Sauvage et Dabry, 1874) is an endemic species of East Asia, widely distributed from southern China to most parts of the Korean Peninsula and western Japan (Chen 1998; Park et al. 2001; Ito et al. 2002; Sakai et al. 2006; Bogutskaya et al. 2008; Takai et al. 2012). In China, $R$. oxycephalus is mainly

\footnotetext{
* Correspondence: xiaoyunsui@ihb.ac.cn

'Laboratory of Biological Invasion and Adaptive Evolution, Institute of Hydrobiology, Chinese Academy of Sciences, No. 7 Donghu South Road, Wuchang District, Wuhan, Hubei Province 430072, China

${ }^{3}$ School of Life Sciences, Peking University, No. 5 Yiheyuan Road, Haidian District, Beijing 100871, China

Full list of author information is available at the end of the article
}

distributed in well-oxygenated montane stream headwaters of Yangtze River Basin (Chen 1998; Zhang and Chen 1997), at the southern-distribution boundary of Rhynchocypris minnows. In its inhabited streams, $R$. oxycephalus often has a large population, acting as the dominant species and playing a crucial role in maintaining the balance of stream ecosystem. Besides, as an important component of local fishery, $R$. oxycephalus also has economic importance. However, with the development of agriculture and industry, most river ecosystems are experiencing severe ecological degradation in China (Chen 2005), making the fish habitats more vulnerable. As indicated by Maxent models, $78.1 \%$ of the most suitable habitats for $R$. oxycephalus would disappear by 2080 , and most range contractions would occur in southeastern China (Yu et al. 2012). 
Worsened by overfishing and water pollution, the population of $R$. oxycephalus is diminishing in recent years.

The life history traits of fish display geographical variations, which are considered as responses to local environment (Vinyoles et al. 2010; Grabowska et al. 2012), and explaining those variations is a central objective of evolutionary biology. Latitude is one of the most important factors that influence several life history traits of freshwater fish (Blanck and Lamouroux 2007). Compared with its closely related species (Rhynchocypris, Phoxinus, and Chrosomus minnows), R. oxycephalus in China is distributed in the lowest latitude regions. The life history traits of many populations of Rhynchocypris, Phoxinus, and Chrosomus minnows have been reported (Starnes and Starnes 1981; Mills and Eloranta 1985; Mills 1987, 1988; Hamed et al. 2008; Wang et al. 2012). However, for $R$. oxycephalus, this information is very limited. There have been only a few publications about its reproductive characteristics and distributions (Xiong 1984; Chen 1998; Yu et al. 2012). Knowing the life history traits of this species may contribute to better understanding of the influence latitude has on the life history traits of freshwater fish. In addition, it is also indispensable for their effective conservation and scientific management, for fundamental links existing between the individual life history and increasing rate of population (Hutchings 2002; Foster and Vincent 2004; Jia and Chen
2011). Both theoretical and empirical analyses showed that certain life history traits made the species more vulnerable to anthropogenic threats (Jennings et al. 1999; Sadovy 2001; Denney et al. 2002; Foster and Vincent 2004).

The objectives of the current study were to (1) present the key life history traits of $R$. oxycephalus under natural conditions, including its age, growth development, and reproduction, to provide essential information for their effective protection and scientific management and (2) compare those traits with its closely related species for better understanding of the influences of latitude and local environment on the stream fish community.

\section{Methods}

\section{Study area}

This study was carried out in the Laohegou Stream (E $104^{\circ} 40^{\prime}, \mathrm{N} 32^{\circ} 31^{\prime}$ ), a montane stream located in the upper Yangtze River drainage, south of China (Figure 1). This stream, with an elevation span of 763 to $1,948 \mathrm{~m}$, drains a surface area of $110 \mathrm{~km}^{2}$ over its $52-\mathrm{km}$ length. It has a typical subtropical monsoon climate, characterized by rainfall mainly occurring in spring and summer. The mean water temperature ranges from $3.78^{\circ} \mathrm{C}$ (in December) to $19.8^{\circ} \mathrm{C}$ (in August), and annual mean water temperature is $11.04^{\circ} \mathrm{C}$. Its $20-\mathrm{km}$ upper reaches and surrounding areas have been established as the

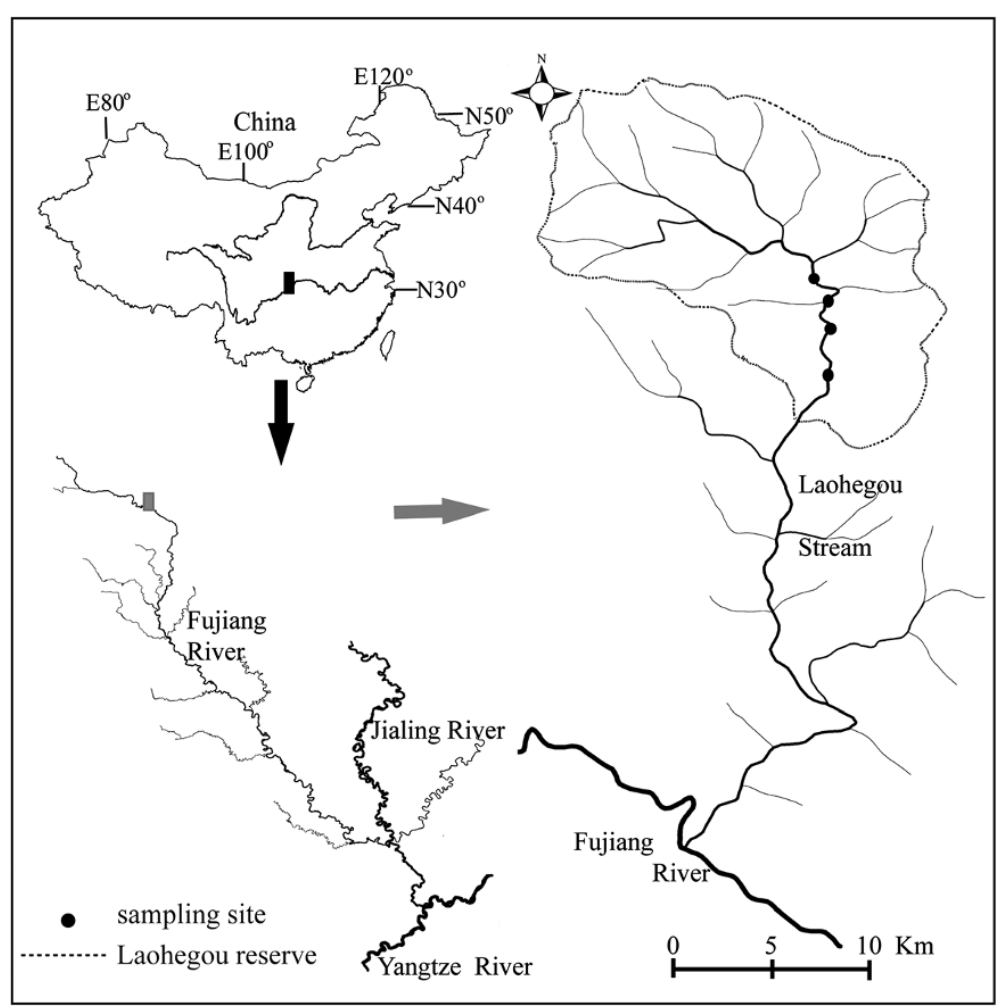

Figure 1 Location of the Laohegou Stream and sampling sites. 
Laohegou Social Welfare Reserve, within which a large amount of $R$. oxycephalus is distributed.

\section{Sample collection and procedures}

From April 2012 to March 2013, 442 individuals were collected by electrofishing at monthly intervals (samplings of January and February 2013 were prevented by bad weather) from four sampling sites (Figure 1). The specimens were individually measured for total length (TL, $0.1 \mathrm{~mm}$ ), standard length (SL, $0.1 \mathrm{~mm}$ ), and weighted body weight (BW, $0.01 \mathrm{~g}$ ) and dissected. Gonad of each specimen was weighted (gonad weight, GW, $0.01 \mathrm{~g}$ ), inspected to determine the sex, and classified into six maturity stages (I-VI) based on the visual traits including profile, size, color, and vascularization, following Yin (1993). Somatic weight (SW, $0.01 \mathrm{~g}$ ) of each specimen has also been recorded. Scales, vertebrae, opercula, dorsal fin spine, and three couples of otolith (asteriscus, lapillus, and sagitta) of each specimen were extracted to determine the age. All processed specimens and mature ovaries at stage IV were preserved in $8 \%$ neutralized formaldehyde solution. Besides, eight environmental variables were recorded during each sampling: longitude, latitude, elevation, dissolved oxygen, wetted width, water depth, water temperature, and current velocity.

\section{Age}

To determine age, every aging material was prepared following Chen et al. (2002). We chose the lapillus for age determination after analyzing and comparing the materials above. For the lapillus, respective distance from the nucleus to the edge (radius, $R$ ) and to the distal edge of each opaque band $(r)$ along the reading zone was measured to the nearest $1 \mu \mathrm{m}$. The periodicity of annulus formation was determined by monthly changes of marginal increment ratio (MIR), using the following equation: $\operatorname{MIR}=\left(R-r_{n}\right) /\left(r_{n}-r_{n-1}\right)$, where $r_{n}$ is the distance between the nucleus and the outer margin of the last opaque mark (Casselman 1987). Age estimation was performed independently by two readers without information of size. Samples with identical readings were used in further age and growth analysis. Ages were also verified using length frequency distribution. Identification of the first annulus in lapillus was confirmed by comparing the total length back-calculated from the first annual to the first peak of total length distribution (Mills 1987).

\section{Growth}

The relationship between TL and BW was described by the exponential equation: $\mathrm{BW}=a \mathrm{TL}^{b}$, where $a$ is the intercept and $b$ is the slope of the regression curve. Difference between sexes for the TL-BW relationship (LWR) was tested using analysis of covariance (ANCOVA) (Sokal and Rohlf 1995). The relative condition factor $\left(K_{\mathrm{N}}\right)$ was used to describe seasonal fluctuations of fish plumpness (Le Cren 1951), which was calculated as $K_{\mathrm{N}}=\mathrm{SW} / \mathrm{PW}$, where PW is the predicted somatic weight at its total length by the TL-SW relationship, and SW is the measured somatic weight. To back-calculate the TL at age, the relationship between TL and radius was described by linear regression: TL $=a+b R$, where $R$ is the radius of lapillus, and $a$ and $b$ are both constants. TL at age was obtained using the Fraser-Lee equation (Duncan 1980): $\mathrm{TL}_{n}=a+(\mathrm{TL}-a) r_{n} / R$, where $\mathrm{TL}$ is the measured total length, $\mathrm{TL}_{n}$ is the back-calculated total length $(\mathrm{BCL})$ at age $n, a$ is the intercept in TL-R linear function, and $r_{n}$ is the distance between core and the $n$th annulus. The von Bertalanffy growth formula (VBGF) (von Bertalanffy 1938) was used to describe the growth curve that fitted to backcalculated data: $\mathrm{TL}_{t}=L_{\infty}\left[1-\mathrm{e}^{-k(t-t 0)}\right]$, where $\mathrm{TL}_{t}$ is the predicted TL at age $t$ (year), $L_{\infty}$ is the theoretical maximum TL, $k$ is the growth rate parameter $\left(\right.$ year $\left.^{-1}\right)$ describing the rate that fish reach $L_{\infty}$, and $t_{0}$ is theoretical initial age (year) when TL is zero. All those parameters were estimated by the least square method. Back-calculation of the VBGF was fitted to males and females, respectively. The growth performance index $\left(\varphi^{\prime}\right)$ was calculated as $\varphi^{\prime}=$ $2 \log _{10} L_{\infty}+\log _{10} k$ (Munro and Pauly 1983). The growth inflexion age $t_{\mathrm{i}}$ (year) was calculated as $t_{\mathrm{i}}=(\ln b) / k+t_{0}$ (Yin 1993), where $b$ is the one in the equation of BW-TL, and $k$ and $t_{0}$ were estimated from the VBGF.

\section{Reproduction}

To calculate the $\mathrm{TL}$ at first maturation $\left(\mathrm{TL}_{\mathrm{m}}, \mathrm{TL}\right.$ at $50 \%$ maturity), the proportion of mature individuals per $5-\mathrm{mm}$ TL intervals was fitted to a logistic function $P i=100(1+$ $\left.\mathrm{e}^{-(a+b \mathrm{TL})}\right)^{-1}$, where $P i$ is the proportion of mature individuals in TL class $i$, and $a$ and $b$ are both constants. The $\mathrm{TL}_{\mathrm{m}}$ was calculated as $\mathrm{TL}_{\mathrm{m}}=-a b^{-1}$ (King 1995). To describe the reproductive effort and gonadal annual cycle, the monthly gonado-somatic index (GSI) was calculated (Yin 1993): $G S I=100(G W / S W)$, where $G W$ is gonad weight and SW is somatic weight. The annual fecundity $(F)$ was estimated as the total number of ripening and ripe oocytes from mature ovaries before spawning (Yin 1993), and relative fecundity (RF) was calculated as (Bagenal 1978) $\mathrm{RF}=F / \mathrm{SW}$. To analyze size frequency distribution of egg diameter in ripened gonads, the diameters of 80 to 100 randomly sampled oocytes were measured during breeding season. Sex ratio was calculated, and its difference from 1:1 was tested by $\chi^{2}$ test (Zar 1999). The present study was carried out following permission issued from the Hubei Province Association for Laboratory Animal Sciences.

\section{Results}

Age

The sectioned lapillus showed clear nucleus and alternating opaque and translucent bands under transmitted 
light (Figure 2). Monthly variations of MIR showed double cyclical trend of increment within 1 year (Figure 3 ). In April and August, the mean MIR decreased while the range of MIR increased, indicating that the opaque band was completed and a new translucent band began to form. Most lapilli taken from specimens in the first peak of total length frequency distribution (70 to $90 \mathrm{~mm}$ ) (Figure 4) were forming (36.8\%) or just formed (46.6\%) their first opaque band. Thus, we considered the first opaque band as their first annulus. We concluded that the lapillus formed one pair of opaque and translucent bands in its first year and then two pairs every year. Consequently, $R$. oxycephalus in this study was aged as follows: individuals with none or one just-formed opaque band were in age 1 group, individuals with one or two opaque bands or having its third opaque band just formed were in age 2 group, individuals with three or four opaque bands or having its fifth opaque band just formed were in age 3 group, and so on for other individuals. The percent agreement among two readers was $94.1 \%$, and the coefficient of variation (CV) was 9.5\%.

For all collected individuals, 153 were identified as females (52.9 to $158 \mathrm{~mm}$, TL), 258 males ( 46.8 to $123.6 \mathrm{~mm}$, $\mathrm{TL}$ ), and 31 juveniles ( 32.2 to $84.3 \mathrm{~mm}, \mathrm{TL}$ ) too young for

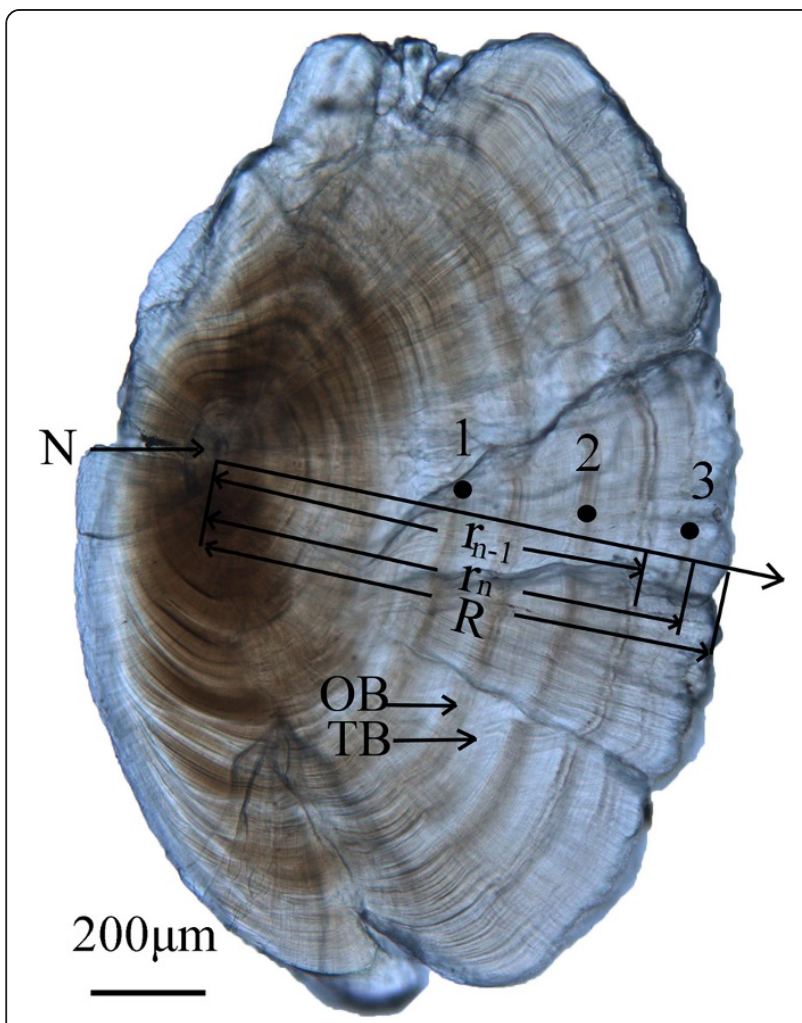

Figure 2 The appearance of a cross section of a 4-year-old $\boldsymbol{R}$. oxycephalus lapillus under transmitted light. N, nucleus; TB, translucent band; OB, opaque band. Solid circles show annuli, and the longest arrow shows the direction of measurement.

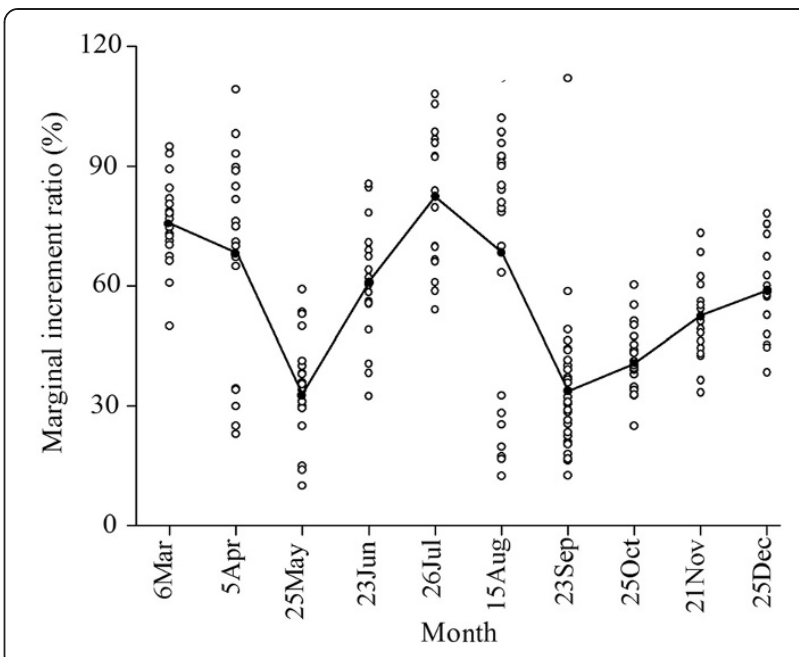

Figure 3 Monthly variations of marginal increment ratio of $\boldsymbol{R}$. oxycephalus lapillus. Solid circles and the line indicate the mean MIR.

sex identification. The sex ratio (females/males) was 1:1.69, which is significantly different from $1: 1\left(\chi^{2}=26.4\right.$, $d f=1, P<0.05)$. Using the sectioned otolith, 416 specimens were successfully aged, and three age groups for males and four age groups for females were observed. Individuals of age 1 (63.7\%) and age 2 (25.5\%) groups dominated the population; only $2.7 \%$ males were in age 3 group and $5.2 \%$ females in age 4 group.

\section{Growth}

The TL-BW equations were as follows: $\mathrm{BW}=1.3 \times 10^{-5}$ $\mathrm{TL}^{2.9298}\left(r^{2}=0.9578, n=258, P<0.05\right)$ for males and $\mathrm{BW}=4.9 \times 10^{-6} \mathrm{TL}^{3.1543}\left(r^{2}=0.9665, n=153, P<0.05\right)$ for females. These equations were significantly different between sexes (ANCOVA, $d f=409, P<0.05$ ). The value of $K_{\mathrm{N}}$ showed two peaks, in March and August, throughout the year. The females and males presented similar

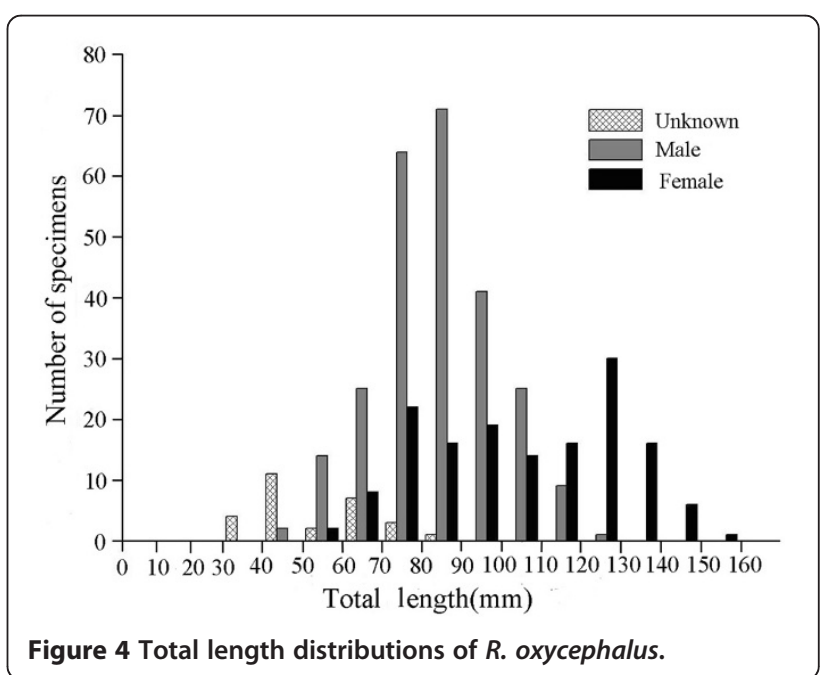


fluctuating patterns of $K_{\mathrm{N}}$ (Figure 5). The relationship between $\mathrm{TL}$ and $R$ was calculated as $\mathrm{TL}=33.907+129.1 R$ $\left(r^{2}=0.8357, n=140, P<0.05\right)$ for females and $\mathrm{TL}=44.46$ $+93.1 R\left(r^{2}=0.6702, n=210, P<0.05\right)$ for males. The difference between the two equations was significant (ANCOVA, $d f=348, P<0.05$ ). The back-calculated TLs at ages (TLs at 3 years for males and at 4 years for females were acquired by measuring the full age individuals) are presented in Table 1 . The body size of males was slightly larger than that of females at age 1 year $(t$ test, $d f=154$, $P<0.05)$ but was smaller at age 2 years $(t$ test, $d f=81$, $P<0.05)$ and age 3 years $(t$ test, $d f=18, P<0.05)$. The length and weight at age for females were described by the VBGF (Figure 6) as $\mathrm{TL}=220.56\left[1-\mathrm{e}^{-0.251\left(t+{ }^{0.80)}\right]}\right.$ and $B W=120.89\left[1-\mathrm{e}^{-0.251(t+0.80)}\right]^{3.1543}$. The VBGF for males was not calculated as their age structure was too simple. Based on $L_{\infty}$ and $k$ values in VBGF, the growth performance index $\left(\varphi^{\prime}\right)$ was 4.09 years and the growth inflexion $\left(t_{\mathrm{i}}\right)$ was 3.78 years for females. The relationship between TL and SL was described by $\mathrm{SL}=0.8279 \mathrm{TL}-$ $0.3439\left(r^{2}=0.9963, n=422, P<0.05\right)$.

\section{Reproduction}

Both females and males reached $50 \%$ maturity at 1 year. The $\mathrm{TL}_{\mathrm{m}}$ was $60.3 \mathrm{~mm}$ for males and $78.8 \mathrm{~mm}$ for females (Figure 7). Among sampled mature individuals, the minimum TLs were 53.6 and $60.0 \mathrm{~mm}$ for males and females, respectively. The monthly variations of GSI presented similar seasonal patterns for females and males (Figure 8). In August, only 9.8\% individuals have mature gonad at stage $V$, and no mature gonad was found in September. Therefore, the breeding season for $R$. oxycephalus in the Laohegou Stream was carried out from April to August.

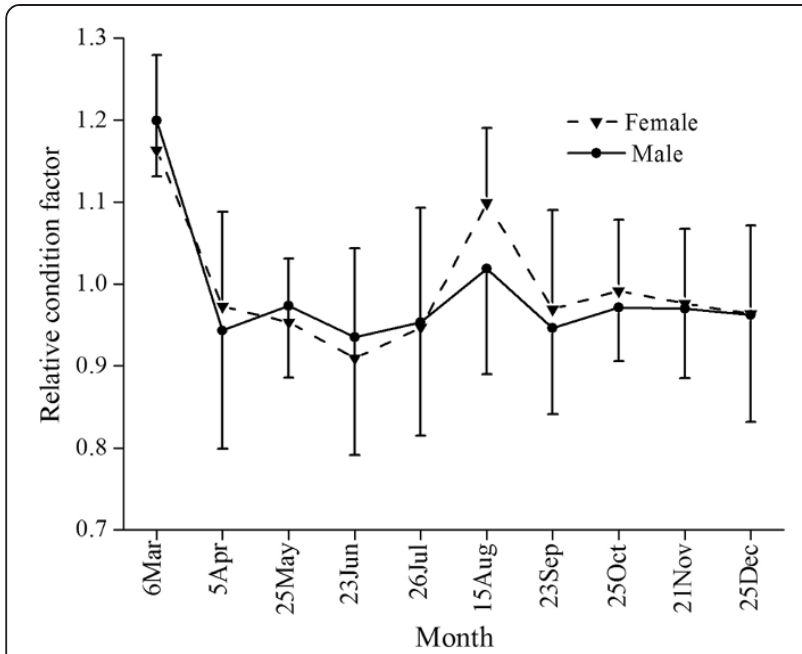

Figure 5 Monthly variations of relative condition factor $\left(K_{N}\right)$ with its respective SD.
Table 1 Back-calculated total length at age of $R$. oxycephalus

\begin{tabular}{lll}
\hline Age (years) & Female & Male \\
\hline 1 & $80.11 \pm 7.06(n=81)$ & $82.75 \pm 4.76(n=75)$ \\
2 & $111.21 \pm 9.87(n=54)$ & $98.92 \pm 6.45(n=29)$ \\
3 & $135.81 \pm 8.15(n=15)$ & $110.42 \pm 1.42(n=5)$ \\
4 & $154.5 \pm 2.89(n=4)$ & \\
\hline
\end{tabular}

Mean \pm SD ( $n=$ number of individuals measured).

The ripened ovaries of $R$. oxycephalus contained groups of oocytes of different sizes, especially at the beginning of the spawning season (Figure 9). In April, ripened oocytes (opaque) constituted about $50 \%$ of all oocytes in ripened ovaries (Figure 9A), and ripening oocytes (semi-transparent) constituted about 35\%; from late June to August, the ripened oocytes constituted about $85 \%$ of all oocytes in ripened ovaries, while few ripening oocytes were found (Figure 9D,E). It can be concluded that the $R$. oxycephalus is a multiple spawner that releases at least two groups of oocytes during breeding season.

In April and May, 27 mature ovaries (at gonadal stage IV) were collected to estimate the annual fecundity $(F)$. The mean $F$ of $R$. oxycephalus was 2,457 oocytes, ranging from 751 (TL at $78.1 \mathrm{~mm}$ ) to 5,189 (TL at $154.2 \mathrm{~mm}$ ). The fecundity was correlated with TL, specified by $F=0.1848 \mathrm{TL}^{2.0073}\left(r^{2}=0.7319, n=27, P<0.05\right)$. Mean relative fecundity was 150 oocytes/g, ranging from 88 oocytes/g to 220 oocytes/g.

\section{Discussion}

\section{Otolith growth pattern}

Otolith is one of the most frequently used aging structures (Campana 2001; Campana and Thorrold 2001). Its sequence of increment is interrupted by checks or discontinuities that mark the occurrence of stressful

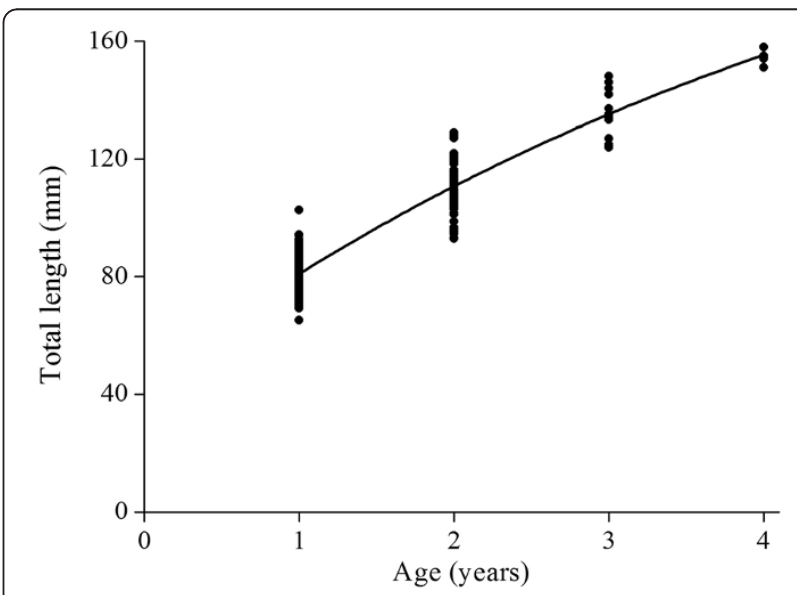

Figure 6 Growth curves of total length in VBGF derived from the back-calculated data. 


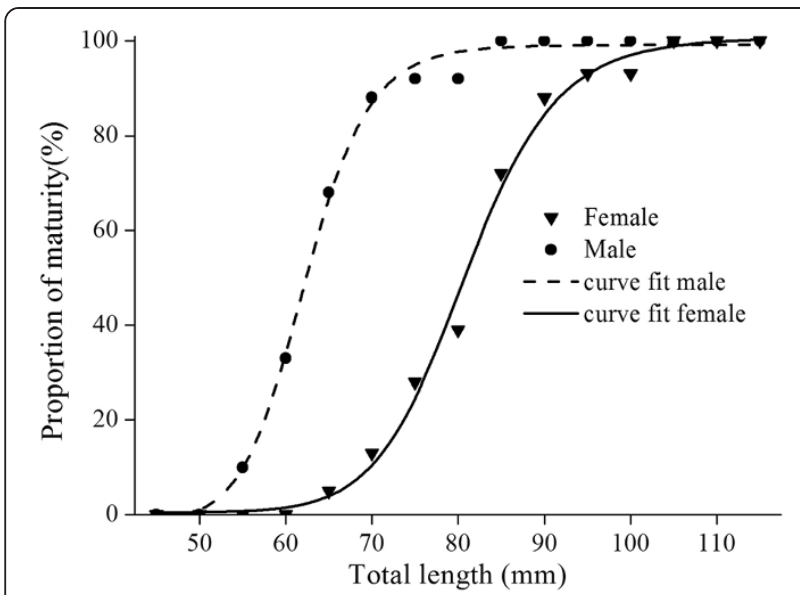

Figure 7 The percentage contributions of mature $R$. oxycephalus in each sequential 5-mm total length intervals.

periods in the life of the fish (Pannella 1974, 1980; Campana 1983; Chen et al. 2002). For riverine fishes, the formation of increments and discontinuities of otolith is mainly influenced by water temperature, water level, and reproductive activity (Welcomme 1979; Mills 1987). In our study, the monthly variations of MIR showed that the otolith of $R$. oxycephalus formed two translucent discontinuous bands during May to early July and September to February, and two opaque incremental bands during March to April and late July to August, separately. We speculated that the first discontinuity (formed during May to July) was mainly caused by the reproductive activity, while the second one (formed during September to February) was mainly caused by the low water temperature and decreased water level. Due to energetic trade-off between somatic growth and reproduction,

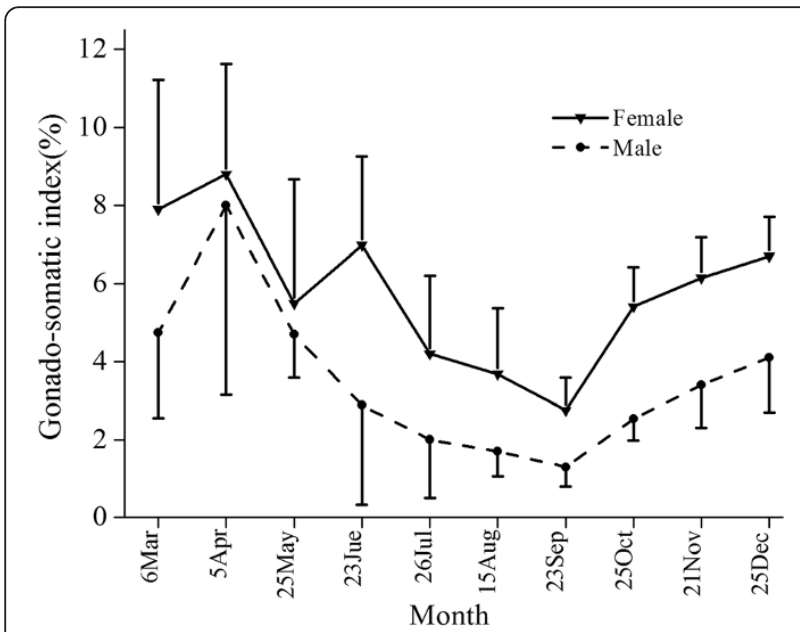

Figure 8 Monthly variations of gonado-somatic index with its respective SD. increasing reproductive effort can lead to decreasing somatic growth rate (Kozlowski 1996; Joanna et al. 2011). During breeding season, the feeding rate of $R$. oxycephalus decreased (unpublished data) while the reproductive effort sharply increased, which, as a result, would put stress on somatic growth. Results from our survey indicated that the rainfall in Laohegou Stream drainage mainly occurred from April to early September, and the water level and the abundance of bait shrunk sharply since mid-September. Along with increasing GSI, large amount of energy would be devoted to the development of gonad. Therefore, the stress of somatic growth of $R$. oxycephalus increased since then. This provides a possible explanation to why the winter in Laohegou Stream drainage began in November, but the forming of the second discontinuity on otolith began in September. The monthly variations of $K_{\mathrm{N}}$, a useful index for assessing the condition of fish independent of fish size (Baigun et al. 2009; Llompart et al. 2013), coincided with our speculation. The $K_{\mathrm{N}}$ of $R$. oxycephalus showed two peak values in March and August, just when the two opaque bands were forming; when the two translucent bands were forming, the value of $K_{\mathrm{N}}$ was low. Mills (1987) suggested that two translucent bands formed on the otolith of Phoxinus phoxinus during summer and winter in southern England; a similar growth pattern was also suggested for the vertebrae of sharks (Pratt and Casey 1983; Branstetter and Musick 1994; Natanson et al. 2002).

\section{Growth}

$R$. oxycephalus in our study presented larger maximum observed TL and faster growth rate than most of its closely related species (Table 2), especially in the early life stage (Figure 10). Results from BCL showed that a large part of individuals had already attained $50 \%$ of the maximum observed TL by age 1 year (Figure 6). The fast growth in the early life stage is a common life history trait adopted by fish living in fluctuating environments like Laohegou Stream (Herrera and Fernandezdelgado 1994; Aparicio and de Sostoa 1998; Ribeiro et al. 2000; Vinyoles et al. 2010), as a bigger body attributes to survive their first harsh season (Baras and Philippart 1999; Duponchelle et al. 2007), i.e., winter. As proved, the growth rate of fish usually varies along the latitudinal gradient (Heibo et al. 2005; Blanck and Lamouroux 2007). The fast growth of $R$. oxycephalus in this study might relate to its lowest latitude distribution. TL distribution and BCL at each age indicated that females grow faster than males and dominated the larger size groups. Larger body could induce females to contribute more energy to reproduction and producing more offspring (Parker 1992), which is significant for the R. oxycephalus to maintain its population in the fluctuating environment. The WLR of $R$. oxycephalus was similar to that of its closely related species (Table 2). 


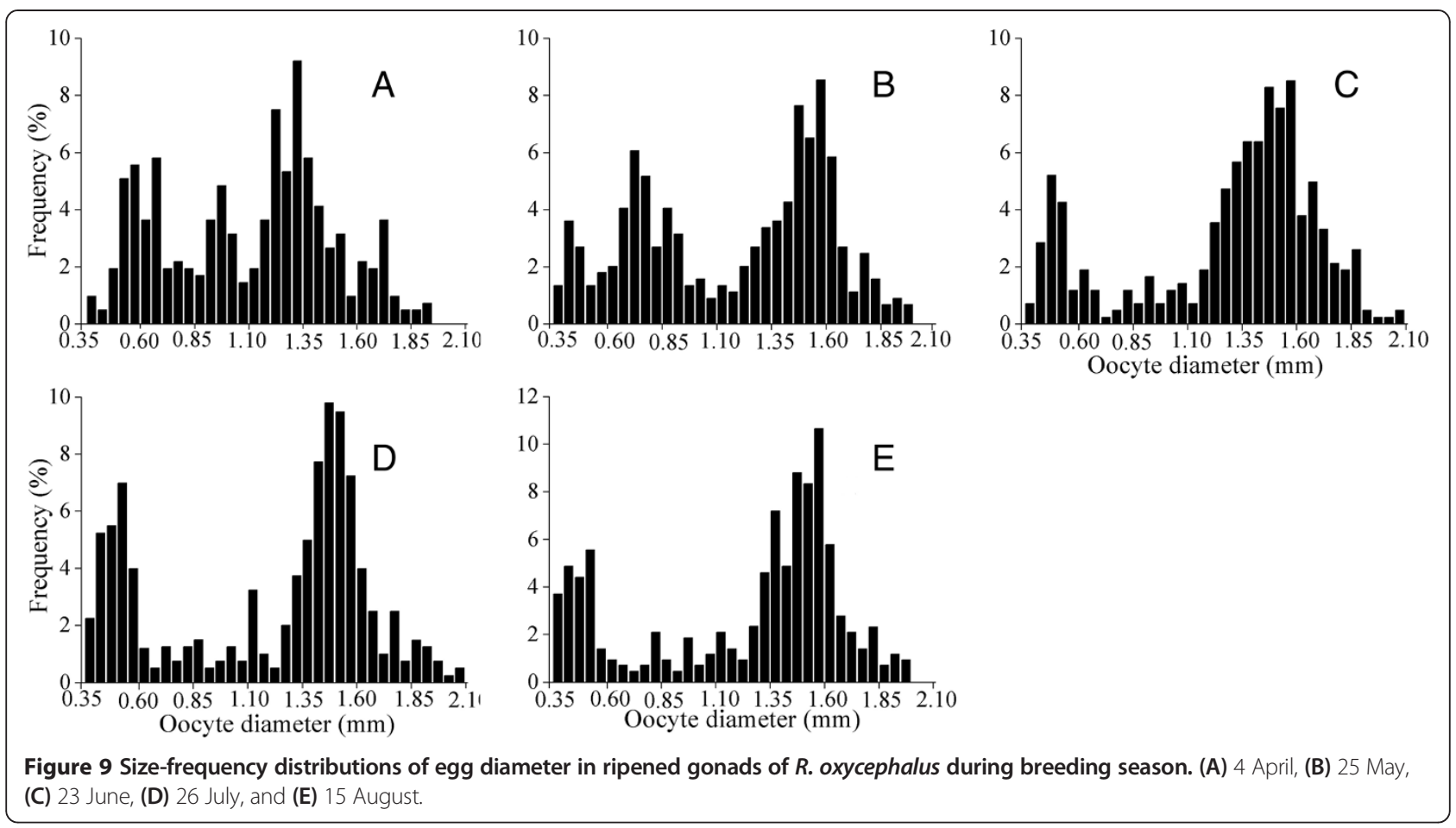

\section{Reproduction}

The logistic model indicated that $50 \%$ sexual maturity of $R$. oxycephalus occurred at 1 year when they reached an $\mathrm{SL}$ of $64.9 \mathrm{~mm}$ for females and $49.6 \mathrm{~mm}$ for males. The age at maturity of its closely related species showed gradual changes along the latitudinal gradient, from 1 to 2 years and up to 6 years, while their SLs at maturity were similar (Table 3). Commonly, the age at maturity would be affected by environmental determinants of growth; populations in lower latitude regions often need less time to reach size for maturation (Clarke et al. 2007). The size and age at sexual maturity are important life history traits, which have profound influence on other life history characteristics such as ultimate body size, mortality, and reproductive success (Stearns 1992; Bernardo 1993; Roff 2002; Barthel et al. 2008). For example, early maturity has side effect on longevity, somatic growth, and fecundity (Heino et al. 2002). The results from the back-calculation of the only four full 4year aged individuals showed that their SLs at 1 year were $53.53,56.78,57.2$, and $57.61 \mathrm{~mm}$, respectively, and their mean SLs at each age were $56.3 \mathrm{~mm}$ (1 year), $89.4 \mathrm{~mm}$ (2 years), and $120.2 \mathrm{~mm}$ (3 years). Those results indicated that none of these four individuals reached maturity at 1 year and their mean growth rate after 1 year was higher than the average of the whole population. So we speculated that early maturity has side effect on the longevity and somatic growth of $R$. oxycephalus.

Table 2 Length-weight relationship parameters of $R$. oxycephalus and closely related species

\begin{tabular}{|c|c|c|c|c|c|c|c|c|}
\hline Species & Location & Coordinates & $n$ & $a$ & $b$ & Length range (mm) & $r^{2}$ & Source \\
\hline \multirow[t]{2}{*}{ R. oxycephalus } & Laohegou Stream & $32^{\circ} 31^{\prime} \mathrm{N}, 104^{\circ} 40^{\prime} \mathrm{E}$ & 258 & $1.3 \times 10^{-5}\left(ठ^{\Uparrow}\right)$ & 2.930 & 46.8 to $123.6(\mathrm{TL})$ & 0.9578 & Present study \\
\hline & & & 153 & $4.9 \times 10^{-6}(q)$ & 3.154 & 52.9 to $158.1(\mathrm{TL})$ & 0.9665 & \\
\hline R. lagowskii & Suifen River & $43^{\circ} 20^{\prime} \mathrm{N}, 130^{\circ} 20^{\prime} \mathrm{E}$ & 193 & $3.67 \times 10^{-5}$ & 2.81 & 24 to $138(S L)$ & 0.93 & Wang et al. (2012) \\
\hline R. percnurus & Suifen River & $43^{\circ} 20^{\prime} \mathrm{N}, 130^{\circ} 20^{\prime} \mathrm{E}$ & 37 & $7.91 \times 10^{-5}$ & 2.65 & 32 to $88(S L)$ & 0.92 & Wang et al. (2012) \\
\hline \multirow[t]{2}{*}{ C. cumberlandensis } & Young's Creek & $37^{\circ} 15^{\prime} \mathrm{N}, 76^{\circ} 43^{\prime} \mathrm{W}$ & 50 & $1.88 \times 10^{-5}\left(\jmath^{\Uparrow}\right)$ & 3.52 & 20 to $67.5(S L)$ & 0.98 & Starnes and Starnes (1981) \\
\hline & & & & $1.86 \times 10^{-5}(q)$ & 2.90 & & 0.94 & \\
\hline P. phoxinus & Atares River & $42^{\circ} 45^{\prime} \mathrm{N}, 0^{\circ} 14^{\prime} \mathrm{W}$ & 27 & $9.1 \times 10^{-6}$ & 3.085 & 31.0 to $74.0(\mathrm{TL})$ & 0.942 & Leunda et al. (2006) \\
\hline P. phoxinus & Middle Gallego & $42^{\circ} 32 \mathrm{~N}^{\prime}, 0^{\circ} 19^{\prime} \mathrm{W}$ & 224 & $5.4 \times 10^{-6}$ & 3.349 & 50.0 to $94.0(T L)$ & 0.929 & Leunda et al. (2006) \\
\hline P. phoxinus & Larraun River & $42^{\circ} 57^{\prime} \mathrm{N}$ to $1^{\circ} 50^{\prime} \mathrm{W}$ & 336 & $4.2 \times 10^{-6}$ & 3.421 & 22.0 to $84.0(\mathrm{TL})$ & 0.97 & Oscoz et al. (2005) \\
\hline P. phoxinus & France & - & - & $1.07 \times 10^{-5}$ & 3.118 & - & - & Oscoz et al. (2005) \\
\hline
\end{tabular}




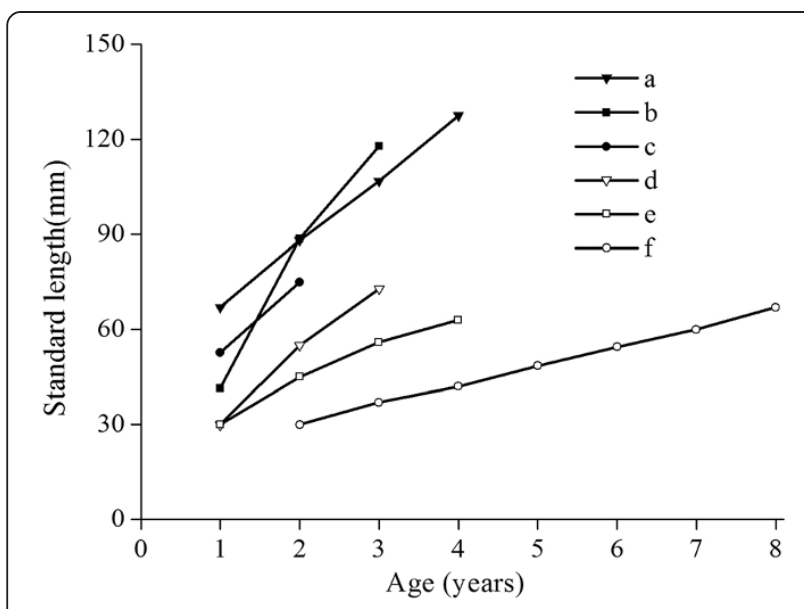

Figure 10 Mean standard length at age for $R$. oxycephalus and closely related species. (a) $R$. oxycephalus in Laohegou Stream $\left(32^{\circ} 30^{\prime} \mathrm{N}, 104^{\circ} 38^{\prime} \mathrm{E}\right),\left(\right.$ b) $R$. lagowski in Suifen River $\left(43^{\circ} 20^{\prime}\right.$ to $44^{\circ}$ $40^{\prime} \mathrm{N}, 130^{\circ} 20^{\prime}$ to $132^{\circ} 30^{\prime} \mathrm{E}$ ), (c) $R$. percnurus in Suifen River $\left(43^{\circ} 20^{\prime}\right.$ to $44^{\circ} 40^{\prime} \mathrm{N}, 130^{\circ} 20^{\prime}$ to $132^{\circ} 30^{\prime} \mathrm{E}$ ), (d) C. tennesseensis in Tennessee stream ( $36^{\circ} 34^{\prime} \mathrm{N}, 82^{\circ} 26^{\prime} \mathrm{W}$ ), (e) P. phoxinus in Frome River (50 $10^{\prime}$

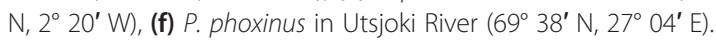

Our study showed that in Laohegou Stream, $R$. oxycephalus spawned from April to mid-August, which was similar with $P$. phoxinus in Frome River and Utsjoki River (Mills 1987, 1988). For Chrosomus tennesseensis in Tennessee Stream and Chrosomus cumberlandensis in Young's Creek, spawning occurred from April to July (Starnes and Starnes 1981; Hamed et al. 2008). P. phoxinus in Konnevesi Lake showed delayed and shortened spawning period, from May to July (Mills and Eloranta 1985). Spawning at an appropriate time plays a crucial role for successful reproduction of fish (Lowe-McConnell 1987; Wootton 1990). For fishes living in fluctuating waters, the spawning season often coincides with local annual flood (Welcomme 1979; Goulding 1980), because flood brings abundant organics from the terrestrial ecosystem into the river ecosystem, increasing the food availability and providing more suitable breeding habitats (Goulding 1980; Lowe-McConnell 1987; Alkins-Koo 2000). The spawning season of $R$. oxycephalus in Laohegou Stream was almost simultaneous with local main rainfall period (from April to early September).

The size frequency distribution of oocytes during the spawning season indicated that $R$. oxycephalus produced batches of oocytes at different times. Repeated spawning over a long breeding period could help avoid a very high density of juveniles at one time, making better use of the diets and thus improving the survival rate of juveniles (Cambray and Bruton 1984; Burt et al. 1988; Vinyoles et al. 2010). This is an important life history trait especially for the fish living in fluctuating environments since it contributes to the recruitment of the populations (Nikolsky 1963). Commonly, the fecundity was postitively associated with body size (Wootton 1990). The $R$. oxycephalus in Laohegou Stream presented the highest fecundity and the largest oocyte among its closely related species that have been reported (Table 3). This is possibly attributable to its large body size. It is well known that larvae hatched from larger oocytes tend to survive better (Ware 1975; Mann and Mills 1979). Early maturity, added by long breeding period and high GSI, indicated a high reproductive effort of $R$. oxycephalus.

\section{Conclusions}

In conclusion, $R$. oxycephalus is a short-lived, fastgrowing, early-maturing, and highly fecund species. Therefore, even a short recovery time after overexploitation or disturbance would be of great use for their restoration. Many life history traits of $R$. oxycephalus are typical traits for species inhabiting fluctuating waters, indicating its great fitness to local environment. Compared with its closely related species that are distributed in higher latitude regions, $R$. oxycephalus grows faster and matures earlier, which may be responses to lower latitude distribution and local environmental conditions.

Table 3 Reproduction parameters of $\boldsymbol{R}$. oxycephalus and closely related species

\begin{tabular}{|c|c|c|c|c|c|c|c|c|}
\hline Species & Location & Coordinates & $\begin{array}{l}\text { Ripe egg } \\
\text { diameter } \\
(\mathrm{mm})\end{array}$ & $\begin{array}{l}S L_{m} \text { for } \\
\text { female } \\
(\mathrm{mm})\end{array}$ & $\begin{array}{l}S L_{m} \text { for } \\
\text { male } \\
(\mathrm{mm})\end{array}$ & $\begin{array}{l}\text { Mature } \\
\text { age } \\
\text { (year) }\end{array}$ & $\begin{array}{l}\text { Spawn } \\
\text { season }\end{array}$ & $\begin{array}{l}\text { Fecundity } \\
\text { (mean } \pm \text { SD) }\end{array}$ \\
\hline R. oxycephalus & Laohegou Stream & $32^{\circ} 31^{\prime} \mathrm{N}, 104^{\circ} 40^{\prime} \mathrm{E}$ & 1.52 & 64.9 & 49.6 & 1 & April to August & $2,457 \pm 1,056$ \\
\hline C. tennesseensis & Tennessee Stream ${ }^{a}$ & $36^{\circ} 34^{\prime} \mathrm{N}, 82^{\circ} 26^{\prime} \mathrm{W}$ & 1.2 & 48.1 & 48.1 & 2 & April to July & $556 \pm 46$ \\
\hline C. cumberlandensis & Young's Creek ${ }^{b}$ & $37^{\circ} 15^{\prime} \mathrm{N}, 76^{\circ} 43^{\prime} \mathrm{W}$ & 0.82 to 1.36 & - & - & 1 & April to July & 1,540 \\
\hline R. lagowskii & Suifen River ${ }^{c}$ & $43^{\circ} 20^{\prime} \mathrm{N}, 130^{\circ} 20^{\prime} \mathrm{E}$ & - & 73.0 & 66.0 & 2 & - & $2,142 \pm 467$ \\
\hline R. percnurus & Suifen River ${ }^{c}$ & $43^{\circ} 20^{\prime} \mathrm{N}, 130^{\circ} 20^{\prime} \mathrm{E}$ & - & 68.0 & 67.0 & 2 & - & $2,567 \pm 303$ \\
\hline P. phoxinus & Frome River $^{d}$ & $50^{\circ} 19^{\prime} \mathrm{N}, 2^{\circ} 20^{\prime} \mathrm{W}$ & 1.3 & 50 & 50 & 2 & April to August & 380 \\
\hline P. phoxinus & Lake Konnevesi ${ }^{\mathrm{e}}$ & $62^{\circ} 36^{\prime} \mathrm{N}, 26^{\circ} 31^{\prime} \mathrm{E}$ & 1.2 & 50.9 & 50.9 & 2 & May to July & $632.6 \pm 112$ \\
\hline P. phoxinus & Utsjoki River $^{f}$ & $69^{\circ} 41^{\prime} \mathrm{N}, 27^{\circ} 06^{\prime} \mathrm{E}$ & 1.2 & 56.2 & 57 & 6 & April to August & 824 \\
\hline
\end{tabular}

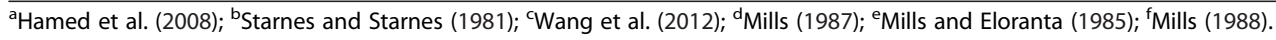




\section{Abbreviations}

ANCOVA: analysis of covariance; BCL: back-calculated total length; BW: body weight; CV: coefficient of variation; F: annual fecundity; GSI: gonado-somatic index; GW: gonad weight; LWR: total length-body weight relationship; MIR: marginal increment ratio; PW: predicted somatic weight; $R$ : radius; RF: relative fecundity; SL: standard length; SW: somatic weight; TL: total length; $T L_{m}$ : $T L$ at 50\% maturity; VBGF: von Bertalanffy growth formula.

\section{Competing interests}

The authors declare that they have no competing interests.

\section{Authors' contributions}

YL carried out the experiments and drafted the manuscript. XS and YC participated in the design and coordination of the study. $\mathrm{YJ}$ and $\mathrm{DH}$ participated in sample collection and data analysis and revised the manuscript. XS finalized the manuscript. All authors read and approved the final manuscript.

\section{Acknowledgements}

This study received financial support from the State Key Program of the National Natural Science Foundation of China (grant no. 41030208), the Sichuan Nature Conservation Foundation (SNCF), and The Nature Conservancy (TNC). We thank Ms. Juan Lei, Mr. Xing-Gui Cai, Mr. Xiang-Hui Chen, and Mr. Peng Zhao for their assistance in sample collection and procedure. We also thank Dr. Wen Xiong, Mr. Juan Tao, Mr. ABM Khaldun, and Ms. Helen for their constructive comments on earlier versions of this manuscript.

\section{Author details}

'Laboratory of Biological Invasion and Adaptive Evolution, Institute of Hydrobiology, Chinese Academy of Sciences, No. 7 Donghu South Road, Wuchang District, Wuhan, Hubei Province 430072, China. ${ }^{2}$ University of Chinese Academy of Sciences, No. 19A Yuquan Road, Beijing 100049, China. ${ }^{3}$ School of Life Sciences, Peking University, No. 5 Yiheyuan Road, Haidian District, Beijing 100871, China.

\section{Received: 28 February 2014 Accepted: 13 June 2014}

\section{Published: 1 July 2014}

\section{References}

Alkins-Koo M (2000) Reproductive timing of fishes in a tropical intermittent stream. Environ Biol Fish 57(1):49-66

Aparicio E, de Sostoa A (1998) Reproduction and growth of Barbus haasi in a small stream in the N.E. of the Iberian peninsula. Arch Hydrobiol 142(1):95-110

Bagenal TB (1978) Aspects of fish fecundity. In: Gerking SD (ed) Ecology of freshwater fish production. Halsted Press, New York, pp 75-101

Baigun CRM, Colautti DC, Grosman F (2009) Assessment of condition in pejerrey Odontesthes bonariensis (Atheriniformes: Atherinopsidae) populations: which index works best? Neotrop Ichthyo 17(3):439-446

Baras E, Philippart JC (1999) Adaptive and evolutionary significance of a reproductive thermal threshold in Barbus barbus. J Fish Biol 55(2):354-375

Barthel BL, Cooke SJ, Svec JH, Suski CD, Bunt CM, Phelan FJS, Philipp DP (2008) Divergent life histories among smallmouth bass Micropterus dolomieu inhabiting a connected river-lake system. J Fish Biol 73(4):829-852

Bernardo J (1993) Determinants of maturation in animals. Trends Ecol Evol 8(5):166-173

Blanck A, Lamouroux N (2007) Large-scale intraspecific variation in life-history traits of European freshwater fish. J Biogeogr 34(5):862-875

Bogutskaya NG, Naseka AM, Shedko SV, Vasil'eva ED, Chereshnev IA (2008) The fishes of the Amur River: updated check-list and zoogeography. Ichthyol Explor Fres 19:301-366

Branstetter S, Musick JA (1994) Age and growth estimates for the sand tiger in the northwestern Atlantic Ocean. T Am Fishe Soc 123(2):242-254

Burt A, Kramer DL, Nakatsuru K, Spry C (1988) The tempo of reproduction in Hyphessobrycon pulchripinnis (Characidae), with a discussion on the biology of 'multiple spawning' in fishes. Environ Biol Fish 22(1):15-27

Cambray JA, Bruton MN (1984) The reproductive strategy of a barb, Barbus anoplus (Pisces: Cyprinidae), colonizing a man-made lake in South Africa. J Zool 204(OCT):143-168
Campana SE (1983) Calcium deposition and otolith check formation during periods of stress in coho salmon, Oncorhynchus kisutch. Comp Biochem Physiol 75:215-220

Campana SE (2001) Accuracy, precision and quality control in age determination, including a review of the use and abuse of age validation methods. J Fish Biol 59:197-242

Campana SE, Thorrold SR (2001) Otoliths, increments, and elements: keys to a comprehensive understanding of fish populations? Can J Fish Aquat Sci 58(1):30-38

Casselman JM (1987) Determination of age and growth. In: Weatherley AH, Gill HS (eds) The biology of fish growth. Academic Press, New York, pp 209-242

Chen Y (1998) Fauna Sinica, Osteichthyes, Cypriniformes. Middle Volume. Science Press, Beijing, pp 75-88, in Chinese

Chen $Y$ (2005) Giving promotions to integrated management of river basins and protecting the life river of the Yangtze. China Water Resour 8:10-13 (in Chinese)

Chen Y, He D, Duan Z (2002) Annuli characters of Selincuo schizothoracine fish (Gymnocypris selincuoensis) in Selincuo Lake, Qinghai-Tibetan Plateau. Acta Zool Sin 41(2):125-133 (in Chinese with English abstract)

Clarke AD, Lewis A, Telmer KH, Shrimpton JM (2007) Life history and age at maturity of an anadromous smelt, the eulachon Thaleichthys pacificus (Richardson). J Fish Biol 71(5):1479-1493

Denney NH, Jennings S, Reynolds JD (2002) Life-history correlates of maximum population growth rates in marine fishes. Proc Biol Sci 269:2229-2237

Duncan KW (1980) On the back-calculation of fish lengths; modifications and extensions to the Fraser-Lee equation. J Fish Biol 16(6):725-730

Duponchelle F, Lino F, Hubert N, Panfili J, Renno JF, Baras E, Torrico JP, Dugue R (2007) Environment-related life-history trait variations of the red-bellied piranha Pygocentrus nattereri in two river basins of the Bolivian Amazon. J Fish Biol 71(4):1113-1134

Foster SJ, Vincent ACJ (2004) Life history and ecology of seahorses: implications for conservation and management. J Fish Biol 65(1):1-61

Goulding M (1980) The fishes and the forest: explorations in Amazonian natural history. University of California Press, Berkeley, p 280

Grabowska J, Pietraszewski D, Przybylski M, Tarkan AS, Marszal L, LampartKaluzniacka M (2012) Life-history traits of Amur sleeper, Perccottus glenii, in the invaded Vistula River: early investment in reproduction but reduced growth rate. Hydrobiologia 661(1):197-210

Hamed MK, Alsop FJ III, Laughlin TF (2008) Life history traits of the Tennessee dace (Phoxinus tennesseensis) in northeast Tennessee. Am Midl Nat 160(2):289-299

Heibo E, Magnhagen C, Vollestad LA (2005) Latitudinal variation in life-history traits in Eurasian perch. Ecology 86(12):3377-3386

Heino M, Dieckmann U, Godo OR (2002) Measuring probabilistic reaction norms for age and size at maturation. Evolution 56(4):669-678

Herrera M, Fernandezdelgado C (1994) The age, growth and reproduction of Chondrostoma polylepis willkommi in a seasonal stream in the Guadalquivir River basin (southern Spain). J Fish Biol 44(1):11-22

Hutchings JA (2002) Life histories of fish. In: Hart PJB, Reynolds JD (eds) Handbook of fish biology and fisheries, vol 1, Blackwell. Oxford, UK, pp 149-174

Ito Y, Sakai H, Shedko S, Jeon SR (2002) Genetic differentiation of the northern Far East cyprinids, Phoxinus and Rhynchocypris. Fisheries Sci 68:75-78

Jennings S, Reynolds JD, Polunin NVC (1999) Predicting the vulnerability of tropical reef fishes to exploitation with phylogenies and life histories. Conserv Biol 13(6):1466-1475

Jia Y, Chen Y (2011) Age structure and growth characteristics of the endemic fish Oxygymnocypris stewartii (Cypriniformes: Cyprinidae: Schizothoracinae) in the Yarlung Tsangpo River, Tibet. Zool Stud 50(1):69-75

Joanna G, Dariusz P, Miroslaw P, Serhan TA, Lidia M, Magdalena L-K (2011) Lifehistory traits of Amur sleeper, Perccottus glenii, in the invaded Vistula River: early investment in reproduction but reduced growth rate. Hydrobiologia 661(1):197-210

King M (1995) Fisheries biology, assessment and management. Blackwell Scientific Publications, Oxford

Kozlowski J (1996) Optimal allocation of resources explains interspecific lifehistory patterns in animals with indeterminate growth. Philos Trans R Soc B-Biol Sci 263(1370):559-566

Le Cren ED (1951) The length weight relationship and seasonal cycle in gonad weight and condition in the perch Perca fluviatilis. J Anim Ecol 20:201-219

Leunda PM, Oscoz J, Miranda R (2006) Length-weight relationships of fishes from tributaries of the Ebro River, Spain. J Appl Ichthyol 22(4):299-300 
Llompart FM, Colautti DC, Maiztegui T, Cruz-Jimenez AM, Baigun CRM (2013) Biological traits and growth patterns of pejerrey Odontesthes argentinensis. J Fish Biol 82(2):458-474

Lowe-McConnell RH (1987) Ecological studies in tropical fish communities. Cambridge University Press, Cambridge, pp 235-269

Mann RHK, Mills CA (1979) Demographic aspects of fish fecundity. Symp Zool Soc Lond 44:161-177

Mills CA (1987) The life history of the minnow Phoxinus phoxinus $(\mathrm{L})$ in a productive stream. Freshwater Biol 17(1):53-67

Mills CA (1988) The effect of extreme northerly climatic conditions on the life history of the minnow, Phoxinus phoxinus (L). J Fish Biol 33(4):545-561

Mills CA, Eloranta A (1985) The biology of Phoxinus phoxinus and other littoral zone fish in Lake Konnevesi, central Finland. Ann Zool Fenn 22(1):1-12

Munro JL, Pauly D (1983) A simple method for comparing the growth of fish and invertebrates. Fishbyte 1:5-6

Natanson L, Mello JJ, Campana SE (2002) Validated age and growth of the porbeagle shark (Lamna nasus) in the western North Atlantic Ocean. Fish Bull 100(2):266-278

Nikolsky GV (1963) The ecology of fishes. Academic Press, London

Oscoz J, Campos F, Escala MC (2005) Weight-length relationships of some fish species of the Iberian Peninsula. J Appl Ichthyol 21(1):73-74

Pannella G (1974) Otolith growth patterns: an aid in age determination in temperate and tropical fishes. In: Bagenal TB (ed) The ageing of fish. Unwin Brothers Ltd, London, pp 28-39

Pannella G (1980) Growth patterns in fish sagittae. In: Rhoads DC, Lutz RA (eds) Skeletal growth of aquatic organisms: biological records of environmental change. Plenum Press, New York, pp 519-560

Park IS, Im JH, Ryu DK, Nam YK, Kim DS (2001) Effect of starvation on morphometric changes in Rhynchocypris oxycephalus (Sauvage and Dabry). J Appl Ichthyol 17(6):277-281

Parker GA (1992) The evolution of sexual size dimorphism in fish. J Fish Biol 41:1-20

Pratt HL, Casey JG (1983) Age and growth of the shortfin mako, Isurus oxyrinchus, using 4 methods. Can J Fish Aquat Sci 40(11):1944-1957

Ribeiro F, Cowx IG, Collares-Pereira MJ (2000) Life history traits of the endangered Iberian cyprinid Anaecypris hispanica and their implications for conservation. Arch Hydrobiol 149(4):569-586

Roff D (2002) Life history evolution. Sinauer Associates, Sunderland, Massachusetts, USA

Sadovy Y (2001) The threat of fishing to highly fecund fishes. J Fish Biol 59:90-108

Sakai H, Ito Y, Shedko SV, Safronov SN, Frolov SV, Chereshnev IA, Jeon S-R, Goto A (2006) Phylogenetic and taxonomic relationships of northern Far Eastern phoxinin minnows, Phoxinus and Rhynchocypris (Pisces, Cyprinidae), as inferred from allozyme and mitochondrial 16S rRNA sequence analyses. Zool Sci 23(4):323-331

Sokal RR, Rohlf FJ (1995) The principles and practice of statistics in biological research, 3rd edn. Freeman and Company, New York

Starnes LB, Starnes WC (1981) Biology of the blackside dace Phoxinus cumberlandensis. Am Midl Nat 106(2):360-371

Stearns SC (1992) The evolution of life histories. Oxford University Press, New York

Takai N, Abiko Y, Tsukamoto H, Miura A, Yuasa K, Itoi S, Nakai S, Sugita H, Yoshihara K (2012) Species identification of upstream fatminnow Rhynchocypris oxycephalus and downstream fatminnow Rhynchocypris lagowskii, based on PCR-RFLP of mitochondrial DNA. Ichthyol Res 59:156-163

Vinyoles D, de Sostoa A, Franch C, Maceda-Veiga A, Casals F, Caiola N (2010) Lifehistory traits of the stone loach Barbatula barbatula. J Fish Biol 77(1):20-32

von Bertalanffy $L$ (1938) A quantitative theory of organic growth (inquiries on growth laws II). Hum Biol 10:181-213

Wang W, Jia YT, Chen YF (2012) Biological characteristics of three economic fishes in Suifen River. J Anhui Norm Univ (Natural Science) 35(5):466-470 (in Chinese with English abstract)

Ware DM (1975) Relation between egg size, growth, and natural mortality of larval fish. J Fish Res Board Can 32(12):2503-2512

Welcomme RL (1979) Fisheries ecology of floodplain rivers. Prentice Hall Press, New York

Wootton RJ (1990) Ecology of teleost fishes, 2nd edn. Kluwer Academic Publishers, Dordrecht, Netherlands

Xiong B (1984) Preliminary study on reproductive biology of Phoxinus lagowskii varicgatus in Shennongjia. Reservoir Fisheries 2:35-39 (in Chinese with English abstract)
Yin M (1993) Ecology of fishes. Chinese Agriculture Press, Beijing (in Chinese) Yu D, Chen M, Zhou Z, Eric R, Tang Q, Liu H (2012) Global climate change will severely decrease potential distribution of the East Asian coldwater fish Rhynchocypris oxycephalus (Actinopterygii, Cyprinidae). Hydrobiologia 700(1):23-32

Zar JH (1999) Biostatistical analysis, 4th edn. Prentice Hall, Upper Saddle River, New Jersey

Zhang E, Chen Y (1997) Fish fauna in northeastern Jiangxi province with a discussion on the zoogeographical division of east China. Acta Hydrobiol Sin 21(3):254-261 (in Chinese with English abstract)

doi:10.1186/s40555-014-0036-0

Cite this article as: Liang et al:: Life history traits of the Chinese minnow Rhynchocypris oxycephalus in the upper branch of Yangtze River, China. Zoological Studies 2014 53:36.

\section{Submit your manuscript to a SpringerOpen ${ }^{\circ}$ journal and benefit from:}

- Convenient online submission

Rigorous peer review

- Immediate publication on acceptance

- Open access: articles freely available online

- High visibility within the field

- Retaining the copyright to your article

Submit your next manuscript at $>$ springeropen.com 